\title{
Treponema pallidum haemagglutination test for yaws Comparison with the TPI and FTA-ABS tests
}

\author{
M. F. GARNER, J. L. BACKhOUSE, G. DASKALOPOUlOS, AND J. L. WALSH \\ Institute of Clinical Pathology and Medical Research, Lidcombe, New South Wales, Australia
}

Similar antibodies are produced in the serum of patients infected with the pathogenic treponemes $T$. pallidum and $T$. pertenue, and for this reason sera from persons with syphilis or yaws react similarly in the conventional tests for syphilis and in the Treponema pallidum immobilization (TPI) and fluorescent treponemal antibody absorption (FTAABS) tests. In the TPI and FTA-ABS tests $T$. pallidum is used as antigen, and these tests are regarded as specific for treponemal infection. The Treponema pallidum haemagglutination (TPHA) test is the latest addition to this group of specific tests.

The TPI test is generally accepted as the most specific test for treponemal infection. However, because of its complexity, its performance is limited to comparatively few laboratories. A specific test is therefore required which has an acceptable sensitivity and specificity and which can be carried out without undue expense.

The pathogenic and non-pathogenic commensal treponemes induce some common or group antibodies, most of which can be removed from serum by absorption with an extract of Reiter treponemes. In the FTA-ABS test this is achieved by the use of sorbent and in the TPHA test by including components of Reiter treponemes in the absorbing diluent. Király, Jobbágy, and Kováts (1967) showed that Reiter treponemes do not always remove all group antibody from serum, and that this was the cause of most borderline and non-specific FTA-ABS test results. It would be reasonable to expect a similar effect in the TPHA test, but this has not been reported so far.

The TPHA test is available commercially in kit form. It is simple to perform and read, and requires no expensive equipment. It was found to be equal in specificity and sensitivity to the FTA-ABS test on syphilitic sera (Garner, Backhouse, Daskalopoulos, and Walsh, 1972) and was considered to be an acceptable alternative to the FTA-ABS test.

Received for publication May 1, 1972

Address: P.O.B. 108, Lidcombe, N.S.W. 2141, Australia
This study was undertaken to compare the results of the TPI, FTA-ABS, and TPHA tests on sera from persons living in areas where yaws was known to be prevalent.

\section{Material and methods}

Sera were examined from 962 persons living in areas of New Guinea and the Northern Territory of Australia where yaws was known to be prevalent. Some cases of active yaws were seen in the younger age groups examined and many of the older subjects showed clinical signs of previous yaws infection. There was no clinical evidence of syphilis in those included in this survey.

Three tests were carried out on each serum using Treponema pallidum as antigen: the Treponema pallidum haemagglutination (TPHA) test, the Treponema pallidum immobilization (TPI) test, and the fluorescent treponemal antibody absorption (FTA-ABS) test. In addition, a cardiolipin Wassermann reaction (CWR), a Venereal Disease Research Laboratory (VDRL) test, and a Reiter protein complement-fixation (RPCF) test were performed on each serum.

The Fuji Zoki Pharmaceutical Company, Tokyo, Japan, manufactured the reagents used in the TPHA test. These included absorbing diluent, not separate absorbent and diluent. The technique used was a qualitative manual micromethod using sera and reagents in the volumes recommended by the Venereal Disease Research Laboratory, Atlanta (1970).

\section{Results}

One serum was found to be unsuitable for TPHA testing. This serum caused agglutination of both the sensitized and unsensitized sheep red blood cells used in the test. This report concerns the remaining 961 sera which were suitable for TPHA testing. The results of the TPHA, FTA-ABS, and TPI tests on the 961 sera in the survey are compared in Table $I$.

The TPHA, TPI and FTA-ABS test results agreed in 812 or 84.5 per cent. of the 961 sera tested. The results of the TPHA test agreed with those of the TPI test in 830 sera $(86.4$ per cent.) and with 
TABLE I TPHA, FTA-ABS, and TPI test results on 961 yaws sera

\begin{tabular}{|c|c|c|c|}
\hline \multirow{2}{*}{ Test } & \multirow{2}{*}{ Result } & \multicolumn{2}{|c|}{$T P H A$ test results } \\
\hline & & Reactive & Non-reactive \\
\hline $\begin{array}{l}\text { FTA-ABS } \\
\text { TPI }\end{array}$ & $\begin{array}{l}\text { Reactive } \\
\text { Reactive }\end{array}$ & 281 & $13^{a}$ \\
\hline $\begin{array}{l}\text { FTA-ABS } \\
\text { TPI }\end{array}$ & $\begin{array}{l}\text { Non-reactive } \\
\text { Non-reactive }\end{array}$ & 110 & 531 \\
\hline $\begin{array}{l}\text { FTA-ABS } \\
\text { TPI }\end{array}$ & $\begin{array}{l}\text { Reactive } \\
\text { Non-reactive }\end{array}$ & $3^{e}$ & $1^{\mathrm{c}}$ \\
\hline $\begin{array}{l}\text { FTA-ABS } \\
\text { TPI }\end{array}$ & $\begin{array}{l}\text { Non-reactive } \\
\text { Reactive }\end{array}$ & $17^{\mathrm{d}}$ & $5^{b}$ \\
\hline Total & & 411 & 550 \\
\hline
\end{tabular}

Note: ${ }^{a}, b, c, d, e$ explained in text

those of the FTA-ABS test in 820 ( 85.3 per cent.). There was some discrepancy between the results of all three tests in 149 sera. Of these, 110 sera $(11.4$ per cent.) were reactive in the TPHA test only. These sera were from persons with no history or clinical evidence of yaws. There were eighteen sera (Table I, $a, b)$ in which the TPHA test result was non-reactive when the TPI gave a reactive result, eighteen sera (Table I, c, d) in which the TPHA and TPI test results agreed and the FTA-ABS test result disagreed, and three sera (Table I, e) in which the TPHA and FTA-ABS tests were reactive and the TPI test non-reactive. The four sera (Table I, c, e) in which the FTA-ABS test gave a $1+$ fluorescence reading and the TPI test gave a non-reactive result, were from persons who showed no clinical evidence of past or present yaws.

Quantitative TPHA tests were carried out on forty sera, which were reactive only in the tests indicated: TPHA (31), TPHA and RPCF (6), and TPHA and FTA-ABS (3). Of these sera twenty had a titre of 80 , ten a titre of 160 , eight a titre of 320 , and two a titre of 1280 . Table II shows the titres of the sera in relation to the three reactive test groups.

\section{Discussion}

The sensitivity of the TPHA test in relation to the TPI test as the standard was $\mathbf{9 4 . 3}$ per cent. and the specificity 82.5 per cent. This compares favourably with the sensitivity $(96.0$ per cent.) and specificity (82.9 per cent.) of the FTA-ABS test related to the TPI test on yaws sera from similar areas (Garner, Backhouse, Cook, and Roeder, 1970). The TPHA test has certain advantages over the FTA-ABS
TABLE II Quantitative TPHA test results on forty sera in which TPI test was non-reactive

\begin{tabular}{|c|c|c|c|c|}
\hline \multirow{2}{*}{ Titre } & \multicolumn{3}{|c|}{ Reactive test results } & \multirow{2}{*}{ Total } \\
\hline & $\begin{array}{l}\text { TPHA } \\
\text { only }\end{array}$ & $\begin{array}{l}\text { TPHA and } \\
\text { RPCF } \\
\text { only }\end{array}$ & $\begin{array}{l}\text { TPHA and } \\
F T A-A B S(1+) \\
\text { only }\end{array}$ & \\
\hline 80 & 15 & 5 & - & 20 \\
\hline 160 & 9 & - & 1 & 10 \\
\hline 320 & 6 & 1 & 1 & 8 \\
\hline 640 & - & - & - & - \\
\hline 1280 & 1 & - & 1 & 2 \\
\hline Total & 31 & 6 & 3 & 40 \\
\hline
\end{tabular}

test-the initial cost is less, all the reagents are available as a complete kit, test results are easier to read, and, unlike fluorescence which fades, can be kept and referred to if necessary.

There were eighteen cases of yaws which would have been missed if the TPHA test results only had been relied upon for diagnosis; of these eighteen sera, which were non-reactive in the TPHA test, five were reactive in the TPI test only and thirteen in both the TPI and FTA-ABS tests.

In seventeen sera the TPI and TPHA tests detected treponemal antibody and the FTA-ABS test failed to do so.

One serum gave a $1+$ fluorescence in the FTAABS test. This was probably a false reactive result as no other test was reactive on this serum, nor did the donor of the serum have clinical signs to support a diagnosis of yaws.

A further three sera showed a $1+$ fluorescence in the FTA-ABS test and a reactive TPHA test result, the CWR, VDRL, RPCF, and TPI tests being nonreactive. The titres of the TPHA tests on these three sera were 160,320 , and 1280 . These results raise the question whether some sera contain group antibody which is not completely removed either by the absorbing diluent used in the TPHA test or by the sorbent used in the FTA-ABS test. The persons from whom these sera were taken gave no history and showed no clinical signs of yaws.

The 110 sera which were reactive in the TPHA test only raised several questions-Was the TPHA test oversensitive? Was the absorbing diluent effective in removing all group antibody from the test sera? Was the TPHA test detecting residual antibody in old cases of yaws in which the TPI and FTA-ABS tests had become non-reactive? Or was it detecting a low antibody level in persons who had been in contact with yaws but had never developed the disease, i.e. similar to those who have antibodies against poliomyelitis without ever having had a clinical infection. 
If it is assumed that these 110 reactive TPHA test results are false positive reactions, then the test was oversensitive in this particular survey of yaws sera. However, this type of result was not found to any significant extent in a recent survey of the TPHA test in syphilis (Garner, Backhouse, Daskalopoulos, and Walsh, 1972). As T. pallidum and T. pertenue are at present antigenically indistinguishable, it seems highly improbable that 11.4 per cent. of the sera tested would show false positive TPHA test results.

It is possible that the Reiter treponeme components in the absorbing diluent used in the TPHA test are, like those in sorbent, not always completely effective in removing all group antibody from all sera. In these circumstances it would be reasonable to expect some of these 110 sera to have shown reactive RPCF or FTA-ABS test results. This did not occur, so it seems an unlikely explanation for all the 110 sera reactive only in the TPHA test.

Of the people tested 586 were adults and 375 children (those under 15 years of age). Sera, reactive in the TPHA test only, were found in $101(17.2$ per cent.) of the adults and in nine $(2 \cdot 4$ per cent.) of the children. Some of these reactive sera found in the adults probably came from people who had had previous treated yaws. It has been shown that in some cases of treated syphilis only the TPHA test may remain reactive, though it was pointed out that the number of sera which showed this was too small for anything but speculation (Garner, Backhouse, Daskapoulos, and Walsh, 1972). A history of previous yaws and treatment was almost impossible to obtain in some areas as records were scanty and clinical information depended largely on the memories of the local inhabitants.

The sera surveyed came from people in 7 areas of New Guinea and the Northern Territory of Australia and, as previously discussed, a reactive TPI test result was taken to indicate yaws (Garner, Hornabrook, and Backhouse, 1971, 1972a, 1972b; Garner, Backhouse, Moodie, and Tibbs, 1972). There was a marked difference in the prevalence of yaws in each of these areas, varying from 69.3 per cent. to 5.0 per cent. It was found that, as the prevalence of yaws increased in these areas, the specificity of the TPHA test decreased (taking the TPI results as the standard for comparison); and the percentage of sera reactive only in the TPHA test tended to increase (Table III). Area 4 had a lower specificity of the TPHA test and a higher percentage of sera reactive only in the TPHA test than was expected from the prevalence of yaws in the area. No explanation could be found for this. In the area having the highest prevalence of yaws seven of the 40 sera showing only TPHA reactive test results were from children. Of the 110 sera which were reactive only in the TPHA test, 31 were tested quantitatively; thirty had low titre results. This increase in sera reactive only in the TPHA tesE in areas of increasing prevalence of yaws leads to speculation whether some of these persons had low antibody levels due to previous contact with yaws; without ever developing the disease clinically.

The TPHA and FTA-ABS tests appear to be equally satisfactory in testing sera for yaws. However, like the FTA-ABS test, the TPHA does not replace the TPI test. The significance of those sera which show reactive results in the TPHA test only and come from those who have no history or clinical signs of yaws, has yet to be determined.

TABLE II P Prevalence of yaws, specificity of TPHA test, and percentage of sera reactive to TPHA test only in each area surveyed

\begin{tabular}{|c|c|c|c|c|c|c|c|c|}
\hline \multirow[t]{2}{*}{ Area } & \multirow{2}{*}{$\begin{array}{l}\text { No. of sera } \\
\text { tested }\end{array}$} & \multirow{2}{*}{$\begin{array}{l}\text { No. of sera } \\
\text { TPI-reactive }\end{array}$} & \multirow{2}{*}{$\begin{array}{l}\text { Per cent. } \\
\text { prevalence } \\
\text { of yaws }\end{array}$} & \multirow{2}{*}{$\begin{array}{l}\text { No. of sera TPI } \\
\text { non-reactive }\end{array}$} & \multirow{2}{*}{$\begin{array}{l}\text { No. of sera } \\
\text { TPI and TPHA } \\
\text { non-reactive }\end{array}$} & \multirow{2}{*}{$\begin{array}{l}\text { Per cent. } \\
\text { specificity } \\
\text { of } T P H A^{\mathrm{a}}\end{array}$} & \multicolumn{2}{|c|}{$\begin{array}{l}\text { Sera reactive in } T P H A \\
\text { only }\end{array}$} \\
\hline & & & & & & & No & Per cent. \\
\hline 2 & 104 & 40 & $38 \cdot 5$ & 64 & 54 & $84 \cdot 4$ & 10 & $9 \cdot 6$ \\
\hline 3 & 176 & 46 & $26 \cdot 1$ & 130 & 111 & $85 \cdot 4$ & 18 & $10 \cdot 2$ \\
\hline 5 & 112 & 26 & $23 \cdot 2$ & 86 & 81 & $94 \cdot 2$ & 3 & $2 \cdot 7$ \\
\hline 6 & 59 & 6 & $10 \cdot 2$ & 53 & 52 & $98 \cdot 0$ & 1 & $1 \cdot 7$ \\
\hline 7 & 64 & 4 & $6 \cdot 3$ & 60 & 59 & $99 \cdot 0$ & 1 & 1.6 \\
\hline 8 & 60 & 3 & $5 \cdot 0$ & 57 & 57 & 100 & - & - \\
\hline
\end{tabular}

a Refers to proportion of sera non-reactive to TPI which were also non-reactive to TPHA 


\section{Summary}

The TPHA test was carried out on 961 sera from areas of New Guinea and the Northern Territory of Australia where yaws was known to occur. The results were compared with those of the TPI and FTA-ABS tests.

The TPHA and TPI test results agreed in 86.4 per cent. of the sera and the TPHA and FTA-ABS test results in 85.3 per cent. The sensitivity of the TPHA test in relation to the TPI test was 94.3 per cent. and the specificity 82.5 per cent. There were 110 sera showing a reactive result in the TPHA test only. The possible causes of this are discussed.

It is concluded that the TPHA test is as satisfactory as the FTA-ABS test in the serodiagnosis of yaws but does not replace the TPI test.

\section{References}

Garner, M. F., Backhouse, J. L., Cook, C. A., and Roeder, P. J. (1970) Brit. F. vener. Dis., 46, 284

- - D, Daskalopoulos, G., and Walsh, J. L. (1972) Ibid., 48, 470

$\longrightarrow$, Moodie P. M,., and TiBbS, G. J.(1972) Bull. Wld Hlth Org., 46, 285

- Hornabrook, R. W., and Backhouse, J. L. (1971) WHO/VDT/71.374

\section{,,--- (1972a) Papua N. Guinea med. F., 15, 136 \\ ,,--- (1972b) Ibid., 15, 139 \\ KirÁly, K., JobbÁgy, A., and Kováts, L. (1967) $\mathcal{F}$. invest. Derm., 48, 98 \\ VenEREAL Disease Research Laboratory, Atlanta (1970) 'Automated Qualitative and Quantitative Micro-Hemagglutination Assay for Treponema palli- dum Antibodies (AMHA-Tp)', Provisional Technique Modified October 20, 1970 \\ Le test d'hémaglutination au Treponema pallidum dans le pian}

SOMMAIRE

Le test TPHA fut pratiqué sur 960 sérums provenant de régions de la Nouvelle Guinée ou du nord de l'Australie où l'on sait que le pian existe. Les résultats furent comparés avec les tests TPI et FTA-ABS.

Les résultats des tests TPHA et TPI furent en accord pour 86,4 pour cent des sérums et, pour les tests TPHA et FTA-ABS, en accord pour 85,3 pour cent. Vis-à-vis du test TPI, la sensibilité du test TPHA fut de 94,3 pour cent et la spécificité de 82,5 pour cent. Cent dix sérums se montrèrent réactifs au seul test TPHA; les causes possibles en sont discutées.

Il est conclu que le test TPHA est aussi satisfaisant que le test FTA-ABS dans le séro-diagnostic du pian, mais qu'il ne remplace pas le test TPI. 